of scientific research in the Air Ministry, paying special attention to jet propulsion gas turbines; at the Ministry of Aircraft Production as director of special projects he became closely associated with all British gas turbine work. In 1944 Dr. Roxbee Cox became chairman and managing director of Power Jets (Research and Development), Ltd., and when it became a Government establishment under the title of the National Gas Turbine Establishment he was appointed director. In 1940 he delivered the Wilbur Wright Memorial Lecture of the Royal Aeronautical Society, speaking on civil aviation, and in 1945 the Wright Brothers Memorial Lecture of the Institute of the Aeronautical Sciences on gas turbines. Last May he was honoured by the Universities of Brussels and Louvain and the Faculté Polytechnique de Hainaut at Mons. At Louvain Dr. Roxbee Cox was presented with the Memorial Medal of the University, and at Mons he was made an honorary member (of whom only five people have been so honoured) of the Association des Ingenieurs de la Faculté Poly. technique de Mons.

\section{Emergency Committee of Atomic Scientists}

"A NEW type of thinking is essential if man is to survive and move to higher levels." These words are quoted from a statement made last summer by Prof. Albert Einstein with which he designed to shock the world out of its complacency. Together with other prominent American men of science he expressed great concern at the use to which mankind would put atomic energy. He recognized that the problem, as Mr. Baruch has so wisely put it, is not one of physics but of ethics, and it is his belief that the only security and hope for mankind lies in a public educated to understand the simple facts concerning atomic energy and their implications for society, for an informed public will surely act for life and not for death.

A million dollars is needed for this great educational task. To collect this money, and to use it in an educational campaign to ensure that atomic energy will be used for the benefit of mankind and not for humanity's destruction, the Emergency Committee of Atomic Scientists, Incorporated, with headquarters at Princeton, New Jersey (Room 28, 90 Nassau Street), has been formed. The trustees are Albert Einstein (chairman), H. C. Urey (vice-chairman), H. A. Bethe, T. R. Hogness, P. M. Morse, L. Pauling, L. Szilard and V. F. Weisskopf. The Committee's programme, as outlined in communications recently received from Prof. Einstein, is to see that the following simple facts, which are accepted by all scientific workers, are given the widest possible publicity. They are: (1) that atomic bombs can now be made cheaply and in quantity, with future bombs likely to be even more powerful and destructive; (2) that there is no military defence against atomic bombs; (3) that other nations can discover for themselves the processes kept secret by the United States ; (4) that preparedness against atomic warfare is futile and, if attempted, will ruin the structure of social order; (5) that if war does occur, atomic bombs will definitely be used, and will surely destroy our civilization; and (6) that international control of atomic energy and, ultimately, the elimination of war, is the only solution to the problem.

The Emergency Committee does not propose to make governmental policy, either at the national or international level, but intends to work through all appropriate educational organisations, including associations such as the Federation of American Scientists, into which, it will be recalled, most of the American' organisations of scientific workers, which sprang into being spontaneously with the dropping of the atomic bomb on Hiroshima and the purpose of which was the study and promotion of atomic energy control, have since been united. The Federation, some time ago, set up a Committee for Foreign Correspondence (Box 615, Berkeley, California) to distribute literature on problems of atomic energy control throughout the world. With financial assistance recently received from the Einstein Emergency Committee, the Foreign Correspondence Committee has now been enabled to widen its activities very considerably. Letters, in a variety of languages, are being sent to scientific and social organisations, libraries, student groups, etc., and also to individuals in more than sixty different countries, in order to keep the public informed of developments in the United States; to develop an important medium for analysing mutual problems; to convince others of the sincerity of American men of science ; and to create sufficient confidence, through friendly contact and understanding, to permit the operation of an international system of atomic control which is one of the keystones of the establishment of world peace.

\section{Mutations Induced by Irradiation of the Substrate}

W. S. Stone, O. Wyss and F. Haas (Proc. U.S. Nat. Acad. Sci., 33, 59; 1947) have discovered that mutations of Staphylococcus aureus may be induced by irradiating the medium with ultra-violet light before inoculation. Even a delay of 30 hours between irradiation and inoculation gave positive results. If the Fildes synthetic medium is irradiated, no growth takes place; this was later shown to result from toxic products of radiated glucose. Irradiation of the mineral salts of this medium gave no positive results, but irradiation of the vitamins and amino-acid fractions resulted in a marked increase of the mutationrate. For example, penicillin-resistant mutants (in the irradiated series) ranged from six to a hundred times as many as in the controls; for resistance to streptomycin there was a similar increase of mutants. It was shown that these mutants were distinct and genetically controlled. Preliminary experiments indicate that it might be possible to induce an increase of a particular gene mutant without affecting others. The activation of the chemicals of the medium may be due to some mechanism involving a shift to a higher energy-level by the absorption of a quantum of energy during irradiation, or a definite change in the chemicals concerned. The substance created is called an 'activated mutator'.

\section{Medical Libraries in the British Isles}

Mr. W. R. LE FANU's paper, "A List of Medical Libraries and Information Bureaux in the British Isles", in the Journal of Documentation of December 1946 is now available separately from the Association of Special Libraries and Information Bureaux (3s.). The list is based on a questionnaire issued by the Association in the autumn of 1944 to libraries known to possess medical collections and to hospitals, medical societies and medical institutions throughout the British Isles. Special libraries of pharmacy and veterinary medicine are included, but not those of anthropology or the biological sciences, except anatomy and physiology. Libraries and information 
bureaux are listed separately, the latter being institutions without libraries which have an active policy of gathering and disseminating information. The annotated lists are arranged alphabetically first for London, and then, separately, those outside London. A list of medical libraries holding periodicals registered in the World List and Union Catalogue is appended with an index of special collections and subjects.

\section{Aerial Photographs for Scientific Purposes}

From time to time aerial photographs are required for scientific purposes. Facilities for such photographs, required for non-commercial scientific purposes, may be provided by the Royal Air Force and Royal Navy, but such facilities are limited, and priority must, therefore, be allocated to the various requirements. The Advisory Committee on Airborne Research Facilities, a joint committee of the Royal Society and the Services, is to advise the Services on this matter. Requirements for photographs to be taken during 1948 should be forwarded to the Committee, at the Royal Society, Burlington House, London, W.1, before October 31,1947 ; it will assist $(a)$ if the envelope is marked 'Aerial Photographs' ; $(b)$ if grid references on the ordnance survey G.S.G.S. $I$ in. series are quoted, alternatively exact latitude and longitude; and $(c)$ if the scale required is stated. (It should be noted that cover is easier to provide in scales of $1 / 10,000$ or $1 / 25,000$.)

\section{University of Birmingham : Appointments}

THE chair of production engineering established two years ago by a munificent gift from Messrs. Joseph Lucas, Ltd., has been filled by the appointment of Dr. T. U. Matthew, director of research of the Bedaux Company for Africa, Ltd. Dr. Matthew's exceptional ability, capacity for research, experience of the technical as well as the production and administrative sides of engineering, his wide interests and scholarly mind will enable him to fill the post with distinction and success. $\mathrm{He}$ had a brilliant career at King's College, London, and in postgraduate research at Cambridge. The chair of production engineering was established "to foster through research the full development of every aspect of Production Engineering and the education through special post-graduate courses of a supply of men who possess not only a sound grasp of the fundamentals of engineering but also a specialized knowledge of production methods and processes and the varied aspects of organisation and control".

The chair of zoology has been filled by the appointment of Mr. P. B. Medawar, lecturer in zoology in the University of Oxford and a fellow of Magdalen College.

Prof. V. G. Childe, professor of prehistoric European archæology in the University of London, has been appointed Mason Lecturer for 1947-48.

\section{Commonwealth Fund Fellowships Awards}

THE Committee of Award of the Commonwealth Fund Fellowships has made the following appointments, among others, to fellowships tenable by British graduates in American universities for one year beginning September 1947: J. P. Bentley, Charing Cross Hospital Medical School and King's College, University of London, to Emory University, Atlanta, Georgia, in surgery ; M. R. Bonham Carter,
Balliol College, Oxford, to the University of Chicago, in political science; R. P. Brittain, University of Glasgow, to New York University College of Medicine, in forensic medicine; A. J. Y. Brown, University of Aberdeen, to the University of California, in economics; W. J. G. Cameron, College of Technology, Queen's University, Belfast, and Queen Mary College, University of London, to the University of Illinois, in engineering; F. J. Dyson, Trinity College, Cambridge, and Imperial College of Science and Technology, University of London, to Cornell University, in mathematics ; F. H. Holmes, University of London, to Princeton University, in chemistry; Dr. James Innes, University of Edinburgh, to Washington University, St. Louis, in medicine; D. S. Jones, Corpus Christi College, Oxford, to the Massachusetts Institute of Technology, in mathematics; Dr. I. C. Jones, University of Liverpool, to Harvard University, in zoology ; James Kenny, University of Glasgow, to Princeton University, in economics; Dr. G. A. Maw, University College, University of London, to Cornell University Medical School, in biochemistry; Bowman Scott, Imperial College of Science and Technology, University of London, to Harvard University School of Business Administration, in engineering ; Alexander Slessor, University of Glasgow, to Harvard University Medical School, in medicine; Dr. Harry Stalker, University of Edinburgh, to Cornell University Medical School, in medicine.

The following have been appointed to fellowships tenable by candidates holding appointments in the Home Civil Service: T. F. Bird, Balliol College, Oxford, and London School of Economics, University of London, of the Ministry of Civil Aviation ; C. E. Calveley, King's College, University of London, of the Post Office; J. A. R. Pimlott, Worcester College, Oxford, of the Lord President's Office; J. B. Williams, MeGill University, and Trinity College, Cambridge, of the Colonial Office (fellowship awarded in 1939).

\section{Announcements}

Aт a Congregation at the University of Cambridge on June 12, eleven honorary degrees were conferred, including that of Sc.D. on : Prof. Linus C. Pauling, professor of chemistry in the Californian Institute of Technology; Sir Edward Mellanby, secretary of the Medical Research Council; Prof. C. T. R. Wilson, emeritus professor of natural philosophy in the University of Cambridge.

Prof. V. G. CHILDE, professor of prehistoric European archæology in the University of London, has been elected a member of the Royal Netherlands Academy of Sciences of Amsterdam (Section of Letters and Historical Sciences).

The Commissioners for the Exhibition of 1851 announce the award of senior studentships for 1947 to the following: On the recommendation of the University of Cambridge : J. S. Courtney-Pratt, for research in physics at the University of Cambridge. On the recommendation of the University of Oxford : D. H. Whiffen, for research in physical chemistry at the University of Oxford ; E. M. Vaughan-Williams, for research in pharmacology at the University of Oxford. On the recommendation of the Imperial College of Science and Technology, London: Dr. K. D. Froome, for research in physics at the Imperial College of Science and Technology, London. 